Loyola University Chicago, School of Law

LAW eCommons

Faculty Publications \& Other Works

2020

Immigration Policy as a Defense of White Nationhood

Juan F. Perea

Loyola University Chicago School of Law, jperea@luc.edu

Follow this and additional works at: https://lawecommons.luc.edu/facpubs

Part of the Immigration Law Commons

Recommended Citation

Juan F. Perea, Immigration Policy as a Defense of White Nationhood, 12 GEO. J. L. \& MOD. CRITICAL RACE PERSPEC. 1 (2020).

This Article is brought to you for free and open access by LAW eCommons. It has been accepted for inclusion in Faculty Publications \& Other Works by an authorized administrator of LAW eCommons. For more information, please contact law-library@luc.edu. 


\title{
Immigration Policy as a Defense of White Nationhood
}

\author{
JUAN F. PEREA*
}

TABLE OF CONTENTS

I. The Framers' Wish for a White America . . . . . . . . . . . . . . . 3

II. The Cycles of Mexican Expulsion . . . . . . . . . . . . . . . 5

III. Deportation and Mass Expulsion: Social Control to Keep America

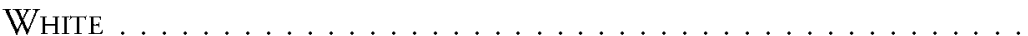

President Trump has declared war on undocumented immigrants. Attempting to motivate his voters before the 2018 mid-term elections, President Trump sought to sow fear by escalating his anti-immigrant rhetoric. "Trump labeled a caravan of Central American refugees seeking asylum as an "invasion" and a "crisis" that demanded, in his view, the use of military troops to defend the U.S. border with Mexico. ${ }^{2}$ When the caravan arrived, the border patrol used tear gas on the refugees, including mothers with infant children. ${ }^{3}$ Trump also referred to undocumented immigrants as criminals, rapists, and gang members who pose a direct threat to the welfare of "law-abiding" people. ${ }^{4}$

Despite the imagery of invasion, crisis, and crime disseminated by President Trump, undocumented immigrants pose no such threats. The number of

* Curt and Linda Rodin Professor of Law and Social Justice, Loyola University Chicago School of Law. (C) 2020, Juan F. Perea. Thanks to Ala Salameh for expert research assistance on this project. Thanks to Valencia Richardson, Cindy Anderson and the editors of the Georgetown Journal of Law and Modern Critical Race Perspectives for their able assistance with this article. The author also appreciates the support of Loyola University of Chicago's Summer Research Grant Program.

1. See Alan Gomez, Central American Migrants Keep Heading Towards USA Even as Trump Focuses on Stopping Caravan, USA TODAY (Jan. 9, 2019), https:/www.usatoday.com/story/news/politics/2019/01/09/ migrant-caravan-trump-crackdown-has-not-slowed-flow-families-us/2523034002/ [https://perma.cd 4HNR-MH8T].

2. Miriam Valverde, Is the Migrant Caravan an Invasion?, POLITIFACT (Nov. 7, 2018), https://www. politifact.com/truth-o-meter/article/2018/nov/07/migrant-caravan-invasion/ [perma.cc/7DBZ-64X4] (calling undocumented immigration a "crisis," the President plans to send 15,000 American troops to defend the border against an alleged "invasion" of 7,000 Central American refugees and asylum seekers, including 2,300 children).

3. Migrant Caravan: Trump Defends Tear Gas on Mexico Border, BBC (Nov. 27, 2018), https://www.bbc. com/news/world-us-canada-46355258 [https://perma.cc/WY2B-B28N].

4. Michelle Ye Hee Lee, Donald Trump's False Comments Connecting Mexican Immigrants and Crime, WASH. POST (July 8, 2015), https:/www.washingtonpost.com/news/fact-checker/wp/2015/07/08/donaldtrumps-false-comments-connecting-mexican-immigrants-and-crime/ [https:/perma.cc/PA54-V649]. 
undocumented immigrants in the United States has remained at about 11 million since 2009-lower than the 12.2 million recorded in 2007. There is neither an "invasion," a "crisis," nor a greater threat now than at any time since 2007. There is no problem of excessive criminality because undocumented immigrants are statistically less likely to commit crimes than native-born Americans. ${ }^{6}$ There is no problem of immigrant freeloading because undocumented immigrants pay an average of $\$ 11.64$ billion a year in state and local taxes and contribute roughly $\$ 80,000$ more in taxes than the cost of government services used over a lifetime. ${ }^{7}$ They are not "taking our jobs" because they contribute to job creation and largely perform undesirable, low-wage jobs. ${ }^{8}$

Immigrants of color on the southern border pose a different sort of threat: they threaten the prevailing conception of the United States as a country controlled and dominated by whites and their culture. This perceived threat has been articulated by advocates of white nativism. For instance, Professor Samuel Huntington described the fear that demographic changes "foretell the replacement of white culture by black or brown cultures that are intellectually and morally inferior."

Because white Americans have varied national origins and different immigration and residential histories, their claim to whiteness provides a common, shared identity. ${ }^{10}$ White nativist ideology provides whites with a way to "construct and legitimize a needed, shared past and national identity." 11 The defense and justification of white nativism is necessary to reinforce whiteness as a shared identity among fairskinned residents of the United States. One scholar describes white nativism as "new white racial advocacy." 12 This Article highlights how the use of immigration and citizenship law to reinforce the shared national identity of whiteness during times of perceived threat has a long and deep history.

To expose this history, the first section of this Article discusses the wish, held by many Framers, that the fledgling nation be a homogeneous nation for white people. The dissonance between that wish and the reality of a diverse American population sets the stage for regulations and expulsions of non-white people. The next section describes how Mexicans were seen as racially inferior by white Americans from the time of their initial contact. Characterizations of Mexicans as an inferior "mongrel race" helped justify mass expulsions of Mexicans and Central Americans, dating back

5. See 7 Ways Immigrant Enrich Our Economy and Society, UNIDOsUS, https://www.unidosus.org/issues/ immigration/resources/facts/ [perma.cc/ZW2W-RVNZ].

6. Id.

7. Id.

8. Id. Evidence shows that undocumented immigrants have little or no long-term adverse effect on wages. Immigrants do not "take" jobs at all. Id. Employers make all decisions about who to hire, including decisions to hire immigrants. Any adverse effects of immigrant employment should be blamed on those responsible, the employers, and not on immigrants who accept jobs and work.

9. Maria del Mar Farina, White Nativism, Ethnic Identity and U.S. Immigration Policy REFORMS 25 (2017) (citing Samuel P. Huntington, The Hispanic Challenge, 141 ForeIGN POL'y 30, 41 (2004)).

10. See id. at $25,31,33,39$.

11. See id. at 26.

12. Carol M. Swain, The New White Nationalism in America: Its Challenge to Integration 15 (2002). 
to the 1930s. Next, this Article describes these mass expulsions which continue into the present. ${ }^{13}$ Despite the refrain about the necessity to secure the border for security reasons, evidence does not support any of the stated justifications for border control. Finally, this Article explores what seems to be the real justification for border control: the need to reassure anxious whites that their dominant place in society remains secure in the face of demographic change.

\section{The Framers' Wish for a White AMERICA}

White supremacy in the American colonies, and later in the United States, was no accident. It began with a theory of white superiority in race and civilization compared to natives and enslaved blacks. The theory of English colonization was to create homogenous, self-sufficient white communities. According to historian George Frederickson, "the assumption that America was meant to be a homogeneous white nation, inhabited chiefly by members of the Anglo-Saxon and closely related 'races,' was strongly established by the time the Constitution went into effect." ${ }^{14}$ 'This view of white homogeneity implied white governance and dominion.

The Framers of the Constitution shared this conception of the country as homogeneous and white. In 1751, Benjamin Franklin expressed his view of white supremacy and exclusivity in the English colonies:

[T] hat the Number of purely white People in the World is proportionably very small. All Africa is black or tawny. Asia chiefly tawny. America (exclusive of the new Comers) wholly so. And in Europe, the Spaniards, Italians, French, Russians and Swedes, are generally of what we call a swarthy Complexion; as are the Germans also, the Saxons only excepted, who with the English, make the principal Body of White People on the Face of the Earth. I could wish their Numbers were increased. And while we are, as I may call it, Scouring our Planet, by clearing America of Woods, and so making this Side of our Globe reflect a brighter Light to the Eyes of Inhabitants in Mars or Venus, why should we in the Sight of Superior Beings, darken its People? why increase the Sons of Africa, by Planting them in America, where we have so fair an Opportunity, by excluding all Blacks and Tawneys, of increasing the lovely White and Red? ${ }^{15}$

Franklin's objection to the importation of Africans reflected a fear that America might "darken its People." ${ }^{16}$ Colonization, in his view, required increasing the number of white people and excluding natives and Africans.

Defending the proposed Constitution, John Jay expressed a view of white American homogeneity like Franklin's. Writing in the Federalist Papers, Jay stated, "Providence has been pleased to give this one connected country to one united

13. See infra notes $73-75$ and accompanying text.

14. George M. Frederickson, White Supremacy: A Comparative Study in American and SOUTH AFriCAN HiSTORY 145 (1981); see also LEON F. LitwaCK, NORTH OF SLAVERY 31 (1961).

15. Benjamin Franklin, Observations Concerning the Increase of Mankind, Peopling of Countries (1751), reprinted in The WORKS OF BENJAMIN FrankLiN, VOl. II LETTERS AND MisC. WRITINGS 1735 1753, 243, 248 (1751) (John Bigelow ed., 1904) (italics original).

16. $I d$. 
people-a people descended from the same ancestors, speaking the same language, professing the same religion, attached to the same principles of government, very similar in their manners and customs." ${ }^{17}$ Jay's statement was, of course, false. The nation contained enslaved blacks, Native Americans, and immigrants from European countries other than England whose ancestors, knowledge, and beliefs differed from the English. Notwithstanding the reality, Jay's conception of a homogenous, white, unified country was meant to increase the appeal of the Constitution to readers of The Federalist Papers.

Thomas Jefferson also imagined a homogeneous white nation. In 1801, Jefferson wrote that:

[I]t is impossible not to look forward to distant times, when our rapid multiplication will expand itself . . \& cover the whole northern, if not the southern continent, with a people speaking the same language, governed in similar forms, \& by similar laws; nor can we contemplate with satisfaction either blot or mixture on that surface. ${ }^{18}$

These wishes for a white, homogeneous nation are at the same time expressions of white supremacy. The all-white male Framers never imagined a government that was not controlled by whites. In the Constitution, they forged a government with representation and powers that would guarantee white dominion. ${ }^{19}$ Thus, it is no accident that the government of the United States has been under virtually exclusive white control since the founding of American colonies about four hundred years ago.

The Framers of the Constitution imagined and engineered a nation by and for white people. The Constitution itself embodied white supremacy and provided tools for continued domination by whites. The Framers drafted a pro-slavery Constitution that both encouraged and protected slave ownership by increasing the political representation of slave owners in the House of Representatives and the electoral college through the Apportionment Clause. ${ }^{20}$ The Framers gave slave owners a constitutional entitlement to recapture their escaped slaves. ${ }^{21}$ They gave Congress plenary constitutional powers over naturalization and the territories. ${ }^{22}$

Congress used its constitutional powers to sculpt and reinforce the Framers' vision of a white nation. In the Naturalization Act of 1790, Congress limited eligibility for naturalized citizenship to "free white persons."23 This white racial qualification for naturalized

17. The Federalist No. 2, at 32 (John Jay) (Clinton Rossiter ed., 2003).

18. Letter from Thomas Jefferson to James Monroe (Nov. 24, 1801), in THOMAS JefFerson: Writings 1096, 1097 (Merrill D. Peterson ed., 1984).

19. See, e.g., the Apportionment Clause, U.S. ConsT. art. I, $\$ 2$, cl. 3, which excluded Indians and counted three-fifths the number of slaves to create greater representation for slave states in Congress and the electoral college; the Fugitive Slave Clause, U.S. CONST. art. IV, $\$ 2$, cl. 3, which created a national right of recaption for slave owners; and naturalization powers, U.S. CONST. art. I, $\$ 8$, cl. 4, which gave Congress the power to shape national demographics by limiting access to naturalized citizenship.

20. SeeU.S. ConsT. art. I, $\$ 2$, cl. 3 .

21. SeeU.S. Const. art. IV, $\$ 2$, cl. 3.

22. SeeU.S. CONST. art. I, $\$ 8, \mathrm{cl} .4$.

23. Kunal M. Parker, Making Foreigners: Immigration and Citizenship LaW in America, $1600-2000,64(2015)$. 
citizenship remained largely unaltered until 1952—only about seventy years ago. ${ }^{24}$ This statute demonstrates that Congress imagined the United States as a nation that reserved full membership for whites only, notwithstanding the presence of non-whites.

Subsequent immigration restriction legislation also sought to reinforce white supremacy by barring the entry of non-white persons and persons perceived to be nonwhite. For example, when white Californians perceived Chinese laborers as a threat to their welfare, Congress enacted the Chinese Exclusion Act of 1882 to curb the perceived threat. ${ }^{25}$ The statute forbade the entry and immigration of Chinese persons. ${ }^{26}$ When whites perceived a threat posed by large-scale immigration from southeastern Europe, whose immigrants were then perceived as non-white, Congress responded with the Immigration Act of $1924 .{ }^{27}$ The 1924 Act curtailed the immigration of southeastern Europeans, then considered non-white, in an attempt to reproduce the white population that existed before $1890 .^{28}$

Despite being perceived as non-white, Mexicans were not excluded under this statute because agriculturalists insisted on uninterrupted access to cheap Mexican laborers. Despite today's continuous demand for cheap and exploitable Mexican and Central American laborers, the reinforcement of white nationhood regularly demands the mass expulsion of millions of undocumented Latino workers.

\section{The CyCles of MeXiCAN Expulsion}

Mexicans have often been perceived to pose a threat to the white purity of the nation. Indeed, the United States' relationship with Mexicans and Mexican Americans has always been rooted in racism. The initial conquest of Mexico from 1846 to 1848 was purportedly justified by the superiority of white Anglo-Saxons who properly deprived "mongrel," despicable, mixed-race Mexicans of their lands. ${ }^{29}$ Approximately half of Mexico was taken in the conquest, constituting roughly onethird of the territory of the United States and virtually the entire Southwest. ${ }^{30}$

The idea of integrating mixed-race Mexicans into the Anglo-Saxon republic of the United States threatened white supremacy and governance. ${ }^{31}$ Some members of Congress, including Senator John Calhoun, even opposed taking Mexican territory because it would mean incorporating Mexicans:

I know further, sir, that we have never dreamt of incorporating into our Union any but the Caucasian race-the free white race. To incorporate Mexico, would

24. Mae M. Ngai, Impossible Subjects: Illegal Aliens and the Making of Modern America 237-38 (2004).

25. Juan F. Perfa et al., Race and Races: Cases and Resources for a Diverse America 411-14 (2d ed. 2007).

26. Id.

27. NGAI, supranote 24 , at 23.

28. $I d$ at $21-23$.

29. PeREA ET AL., supra note 25, at 290-94.

30. See id. at 286-87.

31. See Frederick Merk, Manifest Destiny and Mission in American History 191-92 (1963) (describing how conferring citizenship onto people of color posed a "formidable problem" for Calhoun, the South, the West, and many people in the East). 
be the very first instance of the kind of incorporating an Indian race; for more than half the Mexicans are Indians, and the other is composed chiefly of mixed tribes. I protest against such a union as that! Ours, sir, is the Government of a white race. The greatest misfortunes of Spanish America are to be traced to the fatal error of placing these colored races on an equality with the white race. That error destroyed the social arrangement which formed the basis of society. ${ }^{32}$

In short, according to historian Frederick Merk, "[T] he idea of a wholesale raising to citizenship of the mixed races in Mexico, which seemed inescapable if they were to be absorbed, was horrifying." 33

Just as segregation was a principal strategy for protecting white supremacy and privilege from encroachment by African Americans, Mexicans in the Southwest were subject to the racist rigors of Jim Crow. Lawyer and historian Carey McWilliams described the segregation:

Throughout the citrus belt, the workers are Spanish-speaking, Catholic, and darkskinned, the owners are white, Protestant, and English-speaking. The owners occupy the heights, the Mexicans the lowlands. . . . While the towns deny that they practice segregation, nevertheless, segregation is the rule. Since the Mexicans all live in jim-town, it has always been easy to effect residential segregation. The omnipresent Mexican school is, of course, an outgrowth of segregated residence. The swimming pools in the towns are usually reserved for "whites," with an insulting exception being noted in the designation of one day in the week as "Mexican Day". . . . Mexicans attend separate schools and churches, occupy the balcony seats in the motion-picture theaters, and frequent separate places of amusement. . . The whole system of employment, in fact, is perfectly designed to insulate workers from employers in every walk of life, from the cradle to the grave, from the church to the saloon. ${ }^{34}$

Mexican American children constituted the largest and most frequently segregated racial group in California schools. ${ }^{35}$

Racism targeting Mexicans also found expression in repeated mass deportations of Mexicans over the last century. During times of economic hardship, whites have scapegoated and sought to deport Mexicans in order to eliminate competition for jobs. Mexican (and now Central American) immigrants have long constituted a reserve labor pool subject to expulsion when the need for their labor ends. ${ }^{36}$ As described by Professor Michael Olivas:

Most crucial to the agricultural growers was the need for a reserve labor pool who could be imported for their work, displaced when not needed, and kept in subordinate status so they could not afford to organize collectively or protest their conditions. Mexicans filled this role perfectly, especially in the early twentieth century

32. Cong. Globe, 30th Cong., 1st Sess. 98 (1848).

33. MERK, supranote 31, at 191-92.

34. Carey MCWilliams, SOUThern California Country: AN Island on the Land 219 (1946).

35. Charles Wollenberg, Mendez v. Westminster School District: Race, Nationality and Segregation in California Schools, 53 CAL. HisT. Q. 317, 318 (1974).

36. See Juan Gomez-Quinones, Mexican American Labor, 1790-1990, 89 (1994). 
Southwest, where Mexican poverty and the Revolution forced rural Mexicans to come to the United States for work....[Mexican laborers were] cynically employed to create a reserve pool of temporary laborers who had few rights and no vesting of equities. ${ }^{37}$

The urge to scapegoat brown-skinned immigrants is a form of white racism. Mass expulsions remain a potent, visible enforcement of white supremacy, whether understood as creating employment for whites or addressing white anxieties about demographic change.

Mass deportations of Mexican, and more recently, Central American, migrants have been the largest mass deportations in American history. Yet they remain largely unknown. Although economic duress and competition for scarce jobs have been associated with mass expulsions of Mexicans, these expulsions are also fueled by nativist fears of the contamination of white culture by non-white, non-English speaking Mexicans. In one early episode, large numbers of Mexican immigrants were deported and repatriated in response to a severe economic downturn during 1920-21. ${ }^{38} \mathrm{~A}$ major episode occurred between 1929 and 1936, during the so-called "Mexican Repatriation," when approximately one million Mexicans and Mexican Americans were forcibly expelled from the United States. As described by historian Leo Grebler:

$[\mathrm{L}]$ ocal agencies, saddled with mounting relief and unemployment problems, used a variety of methods to rid themselves of "Mexicans": persuasion, coaxing, incentive, and unauthorized coercion. Special railroad trains were made available, with fare at least to the Mexican border prepaid; and people were often rounded up by local agencies to fill carloads of human cargo. In an atmosphere of pressing emergency, little if any time was spent on determining whether the methods infringed upon the rights of citizens. ${ }^{39}$

About sixty percent of these expelled persons were American citizens, including U.S.-born children of Mexican immigrants. To them, this was not repatriation. It was the forcible deportation of American citizens with no regard for their citizenship or constitutional rights. ${ }^{40}$

During the early 1950 s, and culminating in 1954, the federal government conducted "Operation Wetback," also referred to as "the largest mass deportation of undocumented workers in American history." ${ }^{41}$ Between one and two million persons of Mexican origin, including U.S. citizens, were deported to the interior of

37. Michael A. Olivas, The Chronicles, My Grandfather's Stories, and Immigration Law: The Slave Traders Chronicle as Racial History, 34 ST. LouIs U. L.J. 425, 436-38 (1990).

38. Francisco E. Balderrama \& Raymond Rodriguez, Decade of Betrayal: MeXican REPATRIATION IN THE 1930s, 129 (1sted. 1995).

39. Kevin R. Johnson, The Forgotten "Repatriation" of Persons of Mexican Ancestry and Lessons for the "War on Terror, "26 PaCe L. Rev. 1, 5 (2005) (quoting LeO Grebler, MeXican ImMigration TO THe United STATES: THE RECORD AND ITS IMPLICATIONS 26 (1966)).

40. Id. at $5-8$.

41. Bob Franco Carpinteria, Letter to the Editor: Trip Down Racism Lane, CoASTAL VIEW (Aug. 8, 2018), http:/www.coastalview.com/opinion/trip-down-racism-lane/article_2d2df0b6-9b55-11e8-b024-ab26e178c20e. html [https://perma.cc/9PCJ-JLSQ]. 
Mexico. ${ }^{42}$ According to Immigration and Naturalization Service Commissioner John Swing, mass deportation was necessary because an "alarming, ever-increasing flood tide" of undocumented immigrants threatened "an actual invasion of the United States." ${ }^{43}$ Resembling a full military operation, hundreds of border patrol agents and immigration personnel launched "a direct attack . . . upon the hordes facing us across the border." ${ }^{44}$ One observer described the operation as "poundin' away at these wets." ${ }^{5}$ The removal of Mexicans was meant to be a public spectacle: "To showcase the large numbers of migrants being processed for forced removal into Mexico, officers were directed to raid Mexicano communities, leisure spots, migrant camps, ranches, farms, and parks." 46

These mass deportations ${ }^{47}$ form the proper context for evaluating the present campaign of national vilification and forcible detention and expulsion of Latino immigrants. ${ }^{48}$ Although President Trump has increased the public vilification of Latino immigrants, the presently large number of deportations precedes him. Former President Obama has become known as the "deporter-in-chief" due to vastly increased removal efforts during his presidency. ${ }^{49}$ The numbers tell the story.

During his eight-year term, Obama deported between 2.7 and 3 million undocumented persons - far more than any other president. ${ }^{50}$ Obama was able to deport twice as many Latino people as during Operation Wetback with only slight notice and even less public concern. Between 2003 and 2013, overlapping Obama's first term, 1.3 million persons were removed from the interior of the United States. ${ }^{51}$ These removals included many long-term residents of the United States: nearly fifty percent had been residents for at least three years, and 216,000 lived in the country for at least ten years. ${ }^{52}$ This number is significant because the removal of long-term

42. Id.; Parker, supra note 23, at 204; Bill Ong Hing, Deporting Our SOUls: Values, Morality AND IMMIGRATION POLICY 1 (2009).

43. NGAI, supra note 24 , at 155.

44. Id.

45. Kelly lytle Hernández, Migra! A History of the U.S. Border Patrol 190 (2010).

46. Id. at 186 .

47. The scale of deportations of Mexicans and Central Americans is unprecedented. Consider other mass deportations and exclusions of non-white people: Indian Removal displaced about 80 to 100,000 native Americans; Japanese internment affected about 120,000 Japanese American citizens and aliens; and Chinese exclusion affected an unknown number of Chinese immigrants who were prohibited from returning if they

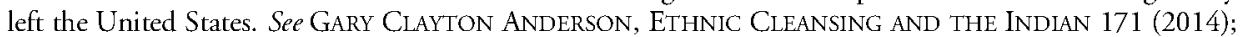
Erin Blakemore, "The Largest Mass Deportation in American History," History (June 18, 2019), https:// www.history.com/news/operation-wetback-eisenhower-1954-deportation [https:/perma.cc/5ANN-UB8Z].

48. See, e.g., Isaac Chotiner, How the Stress of Separation and Detention Changes the Lives of Children, NEW YORKER (July 13, 2019), https:/www.newyorker.com/news/q-and-a/how-the-stress-of-separation-anddetention-changes-the-lives-of-children [https://perma.cc/9YQU-4P7V]. Of course, there have been other major expulsions and detentions of non-white peoples, including American Indian Removal, Chinese exclusion, and Japanese American internment. See PEREA, supra note 25, at 394-407, 436-40.

49. See Tanya Golash-Boza, President Obama's Legacy as "Deporter in Chief", in David C. Brotherton \& Phillip Kretsedemas, immigration policy in the Age of Punishment: Detention, DEPORTATION, AND BORDER CONTROL 38-53 (2017).

50. Id at 39 .

51. Id. at 45 .

52. Id. 
immigrants causes the most harm to families and communities. ${ }^{53}$ From 2010 to 2012,204,810 deportations-about twenty-five percent of the total number of deportations - targeted the parents of U.S. citizen children, thus forcibly depriving these children of their parents. ${ }^{54}$ Although Obama's public statements emphasized the deportation of criminal aliens, the statistics show that most of the people expelled committed minor traffic and drug offenses or were labelled "criminal" merely for crossing the border without papers. ${ }^{55}$

While continuing large-scale deportations, President Trump has increased the vilification of undocumented Latino migrants to appeal to his conservative base. ${ }^{56}$ His rhetoric uses exactly the same tropes as the anti-Latino discourse of the twentieth century. ${ }^{57}$ Trump has consistently dehumanized undocumented persons, likening them to rapists, gang members, animals, and even terrorists. ${ }^{58}$ During his presidential campaign, Trump said,

When Mexico sends its people, they're not sending their best. They're sending people that have lots of problems and they're bringing those problems. They're bringing drugs. They're bringing crime. They're rapists. And some, I assume, are good people. ${ }^{59}$

More recently he said, "These aren't people. These are animals." 60 He has also deemed undocumented immigration to be an "infestation," as though he were describing household pests: Trump tweeted, "[Democrats] don't care about crime and want illegal immigrants, no matter how bad they may be, to pour into and infest our country, like MS-13."61

Beyond racist rhetoric, we have witnessed the forcible separation of immigrant children torn from their families, evoking the sorry history of slave auctions that tore

53. Bob Franco Carpinteria, Trip Down Racism Lane, COASTAL VIEW (Aug. 8, 2018), http://www. coastalview.com/opinion/trip-down-racism-lane/article_2d2df0b6-9b55-11e8-b024-ab26e178c20e.html [https://perma.cc/9PCJ-JLSQ].

54. Id. at 49 .

55. See id.

56. Sarah Coleman, Sorry, Trump. Ike's Shameful Program Failed, CNN (Nov. 12, 2015), https://www. cnn.com/2015/11/12/opinions/coleman-operation-wetback/index.html [https://perma.cc/RB57-SVFL] (noting that during Republican presidential debates, Trump praised former President Dwight Eisenhower for Operation Wetback, crediting him for moving "a million and a half illegal immigrants out of this country").

57. See FARINA, supra note 9, at 24-25 (detailing the origin of white nativism as a social construct to contrast Anglo-Saxon inhabitants from other groups of immigrants in the United States).

58. Katie Reilly, Here Are All the Times Donald Trump Insulted Mexico, Time (Aug. 31, 2016), http:// time.com/4473972/donald-trump-mexico-meeting-insult/ [https://perma.cc/NUK6-J9YN].

59. Gregory Korte \& Alan Gomez, Trump Ramps up Rhetoric on Undocumented Immigrants: "These Aren't People. These Are Animals, "USA TODAY (May 16, 2018), https://www.usatoday.com/story/news/politics/ 2018/05/16/trump-immigrants-animals-mexico-democrats-sanctuary-cities/617252002/ [https:/perma.cc/ 9YUH-CJ66].

60. $I d$.

61. Abigail Simon, People Are Angry President Trump Used This Word to Describe Undocumented Immigrants, Time (June 19, 2018), http://time.com/5316087/donald-trump-immigration-infest/ [https:// perma.cc/F583-RSWB]. 
apart black families for profit. $^{62}$ The family separation policy caused immeasurable pain and psychological damage, and even resulted in at least two deaths by suicide. ${ }^{63}$ Although public backlash forced Trump to abandon the policy, even at the time of this writing, over one thousand immigrant children remain orphaned, with uncertain prospects of ever seeing their parents again. ${ }^{64}$

The recent caravan of undocumented refugees and asylum seekers from Central America inspired Trump to escalate his rhetoric even further. With no evidence to support the claim, Trump asserted that the caravan of refugees contained "[c]riminals and unknown Middle Easterners," 65 evoking the stereotypical threat of terrorism. Trump characterized the refugees as an "invasion" justifying military preparedness: "Many Gang members and some very bad people are mixed into the Caravan heading to the Southern border. . . This is an invasion of our country and our Military is waiting for you." 66 Trump even sent five thousand military troops to the southern border for an unspecified "support" mission ${ }^{67}$ that appeared to be completely unnecessary.

And then, there is the wall. The construction of a "big, beautiful wall," across the border of Mexico has been among Trump's loudest, most frequent, and most popular promises. ${ }^{68}$ Despite the opinion of a majority of Americans that the wall is unnecessary, ${ }^{69}$ Trump has gone so far in his pursuit of a wall as to cause a government shutdown and to declare a national emergency. ${ }^{70}$

62. Adam Serwer, Trumpism, Realized, ATLANTIC (June 20, 2018), https://www.theatlantic.com/ideas/ archive/2018/06/child-separation/563252/ [https://perma.cc/77US-YJTC].

63. Nick Miroff, Father "Took His Own Life" After He Was Separated from Family by Border Agents, INDEPEND. (June 10, 2018), https:/www.independent.co.uk/news/world/americas/father-us-border-patrolseparated-family-marco-antonio-munoz-honduras-a8392006.html [https://perma.cc/PH8G-AKBQ]; Joel Rose, DHS Watchdog Finds "Significant Health and Safety Risks for Immigrants at ICE Center,"NPR (Oct. 2, 2018), https:/www.npr.org/2018/10/02/653802676/dhs-watchdog-trump-administration-wasnt-readyfor-family-separation [https://perma.cc/EQE2-BZZU].

64. Dara Lind, It's Official: We'll Never Know the Real Scope of Trump's Family Separation Crisis, Vox (Jan. 17, 2019), https:/www.vox.com/policy-and-politics/2019/1/17/18186773/families-children-separatedtrump-thousands [https://perma.cc/CVB7-25U5].

65. David Roberts, The Caravan "Invasion" and America's Epistemic Crisis, Vox (Nov. 2, 2018), https:// www.vox.com/policy-and-politics/2018/11/1/18041710/migrant-caravan-america-trump-epistemic-crisisdemocracy [https://perma.cc/5GUT-EYPD].

66. Jeremy W. Peters, How Trump-Fed Conspiracy Theories About Migrant Caravan Intersect with Deadly Hatred, N.Y. Times (Oct. 29, 2018), https://www.nytimes.com/2018/10/29/us/politics/caravan-trumpshooting-elections.html [perma.cc/Q7CV-H7JR].

67. Alicia Caldwell \& Nancy Youssef, Trump to Deploy 5,200 Troops to Southern Border, WaLL ST. J. (Oct. 30, 2018), https://www.wsj.com/articles/military-to-deploy-5-000-troops-to-southern-border-u-sofficials-say-1540820650 [perma.cc/5M6A-DQF4].

68. See The Big, Beautiful Border Wall America Built Ten Years Ago, ECONOMIST (Nov. 22, 2018), https:// www.economist.com/united-states/2018/11/24/the-big-beautiful-border-wall-america-built-ten-years-ago [perma.cc/J5DK-B8PK].

69. John Gramlish, How Americans See Illegal Immigration, the Border Wall, and Political Compromise, PEW RES. CTR. (Jan. 16, 2019), http://www.pewresearch.org/fact-tank/2019/01/16/how-americans-seeillegal-immigration-the-border-wall-and-political-compromise/ [perma.cc/3VAJ-R54Z].

70. Jacob Pramuk, Trump Declares National Emergency to Build Border Wall, Setting up Massive Legal Fight, CNBC (Feb. 15, 2019), https://www.cnbc.com/2019/02/15/trump-national-emergency-declarationborder-wall-spending-bill.html [perma.cc/7MGT-LKHC]. 
Though dismissed as ineffective for border control by experts, ${ }^{71}$ the true rationale for the wall is to reassure anxious whites that their color and culture are being defended. In the words of sociologist Douglas Massey, the wall "sends a clear signal to supporters [of President Trump] that Mexico and Mexicans are a threat to the nation, Latino immigrants are unfit for inclusion in [U.S.] society, and our neighbors to the south are not and will never be accepted as 'real Americans." 72

\section{Deportation and Mass Expulsion: Social Control to KeEp America WHITE}

The repeated, cyclical expulsion of Latino immigrants for imagined harms demonstrates that Latinos remain uniquely expendable in the United States. Indeed, there seems to be a national consensus on the expendability of Mexicans and Central Americans. Both Democratic President Obama and Republican President Trump have enforced draconian immigration policies against brown immigrants from the southern border. ${ }^{73}$ Obama increased deportations to demonstrate that Democrats would be tough on border enforcement and to induce Republicans to negotiate immigration reform legislation. Most of Obama's expulsions, however, occurred well after it became clear that Republicans would not negotiate on immigration reform legislation or anything else. ${ }^{74}$ There seems to have been no compelling reason for expelling millions of hardworking people after it became clear that Republicans would not work with him. While Trump has increased the volume and hostility of antiimmigrant discourse, he has largely followed in Obama's deportation footsteps. And although Trump's hostile, racist rhetoric has been criticized, there was little objection to the actions he took to capture and expel undocumented immigrants, until he forcibly separated children from their parents at the border. ${ }^{75}$

This truth demonstrates a national consensus on the expendability of Mexicans and Central Americans. Regardless of the evidence showing that there is no

71. Wall Would Be "Wasteful and Ineffective," Says Former Homeland Security Chief Napolitano, PuB. RADIO INT'L (Jan. 10, 2019), https://www.pri.org/stories/2019-01-10/wall-would-be-wasteful-andineffective-says-former-homeland-security-chief [perma.cc/8D7P-7T5U].

72. Douglas S. Massey, Afterwords: The Real Purpose of the Border Wall in ROBERT SCHENKKAN, Building the Wall: The Play and Commentary 109 (2017).

73. See Mitra Ebadolahi, The Border Patrol Was Monstrous under Obama. Imagine How Bad It Is under Trump, ACLU (May 23, 2018), https:/www.aclu.org/blog/immigrants-rights/ice-and-border-patrol-abuses/ border-patrol-was-monstrous-under-obama-imagine [perma.cc/248H-J8PY].

74. Daniel Foster, Obama's Immigration Speech: Republicans Want a 'Moat with Alligators, 'NAT'L REV. (May 11, 2011), https://www.nationalreview.com/corner/obamas-immigration-speech-republicans-wantmoat-alligators-daniel-foster/ [perma.cd/3JRX-55J5]; see also Jessica Bolter et al., The Obama Record on Deportations: Deporter in Chief or Not?, MIGRATION POL'Y (Jan. 26, 2017), https://www.migrationpolicy. org/article/obama-record-deportations-deporter-chief-or-not [perma.cc/4K94-6QBB].

75. See Robert Draper, The Democrats Have an Immigration Problem, N.Y. Times (Oct. 10, 2018), https://www.nytimes.com/2018/10/10/magazine/the-democrats-have-an-immigration-problem.html [perma.cd ESL4-7VDH]. The separation of children provides poignant evidence of the second-class status of Latino American citizens. Unlike most American children, American-born Latino citizen children can be forcibly deprived of their parents with little or no due process rights. 
immigration problem, ${ }^{76}$ both Democrats and Republicans agree on the necessity for additional border control measures, if not a wall. ${ }^{77}$ But if there is no actual immigration problem, why is it necessary to further fortify the border? To the extent that there are crimes at the border, crime control measures might be necessary. But actual crime control does not justify expelling mostly innocent immigrants and rejecting refugees seeking asylum. It is striking that hardly anyone is defending current levels of immigration nor making the case that more immigration might be positive and possibly necessary. Just as reunion among northern and southern whites after Reconstruction was accomplished through the abandonment of southern blacks, so does convergence between liberal and conservative whites occur through tacit acceptance of the expendability of undocumented Latino immigrants. ${ }^{78}$

Again, Latino immigrants are being expelled and vilified to reassure a significant segment of the population that the whiteness of the nation is being defended. White Americans feel reassured by anti-brown-immigrant public policy because they perceive President Trump and his administration to be defending the privileged status of white identity. By excluding Latinos, Trump reassures frightened white Americans that their culture will be defended against the perceived toxicity of "intellectually and morally inferior" brown and black cultures.

American immigration and citizenship law has long been used to defend white status and privilege. ${ }^{79}$ The use of immigration and citizenship law in defense of white nationhood illustrates that white nativism is the same as white supremacy; it is white supremacy displaced onto a native-foreigner binary. To see this, one need only recognize that many prominent defenses of white supremacy have succeeded using the laws of immigration and citizenship. The 1790 Naturalization Act reserved full citizenship for free whites only. The infamous Dred Scott decision denied Scott and other blacks the possibility of federal citizenship. ${ }^{80}$ The outright exclusion of Chinese laborers and the classification of Chinese and Japanese laborers as aliens ineligible for citizenship made them subordinate to whites. ${ }^{81}$

As if to underline the white supremacist meaning of current immigration law enforcement, all of the present efforts at border control and deportation are targeted at people of color from south of the border. ${ }^{82}$ There is no clamor to forbid the entry

76. Stuart Anderson, There Is No Crisis at the Border, and DHS Stats Prove It, ForBeS (June 25, 2018), https://www.forbes.com/sites/stuartanderson/2018/06/25/there-is-no-crisis-at-the-border-and-dhs-statsprove-it/\#64b80bc9112a [perma.cc/XD4P-QE9N].

77. Li Zhou, Congress Just Passed a Border Security Deal, Vox (Feb. 14, 2019), https://www.vox.com/ policy-and-politics/2019/2/14/18224457/congress-border-security-deal [perma.cc/RYR9-EPCY].

78. See David W. Blight, Race and Reunion: The Civil War in american Memory 137-39 (2001).

79. FARINA, supra note 9, at 31-32.

80. See Dred Scott v. Sandford, 60 U.S. (19 How.) 393, 405 (1857) (holding the Framers never intended federal citizenship for African Americans, therefore Dred Scott lacked the ability to sue in federal court based under diversity jurisdiction).

81. NGAI, supranote 24 , at $93-94$.

82. Micah Luxen et al., Is There a Crisis on the US-Mexico Border?, BBC, (July 11, 2019), https://www. bbc.com/news/world-us-canada-44319094 [https://perma.cc/PB3S-2S6M]. 
of white immigrants from Ireland, Poland, or Norway. ${ }^{83}$ There is no perceived threat looming at the spacious, unsecured Canadian border. There is no clamor for a northern border wall. ${ }^{84}$

Legal scholars argue persuasively that the criminal justice system has become a system of racial control primarily to control black men. ${ }^{85}$ Less attention has been paid to the parallel use of immigration and citizenship law as a system of racial and demographic control. Yet the parallels and the outcomes are unmistakable. Like the victims of mass incarceration, thousands of undocumented immigrants languish in immigration detention. ${ }^{86}$ Like police violence against unarmed African Americans, the state inflicts violence without accountability against the undocumented. The forcible separation of families and the deaths of immigrant children in custody make this point clear. $^{87}$

The use of the naturalization and immigration powers to halt, deport, expel, and break families of undocumented immigrants families of their identity is part of a long history of largely successful attempts to curtail the nonwhite population of the country. ${ }^{88}$ Racism expressed through naturalization and immigration law is nothing new. The currents of American racism, now packaged as white nativism, run very deep and very long.

83. David A. Graham, Why Trump Can't Understand Immigration from 'Shithole Countries,' ATLANTIC, (Jan. 11, 2018), https:/www.theatlantic.com/politics/archive/2018/01/trump-haiti-el-salvador-africa/ 550358/ [https://perma.cc/V5SW-DY47].

84. Luxen, supra note 82.

85. See generally MiCHELle ALEXANDER, THE NEW Jim CROW (2012).

86. United States Immigration Detention, Global Detention Project (May 2016), https://www. globaldetentionproject.org/countries/americas/united-states [https://perma.cc/FC36-FN5N].

87. See What My 6-Year-Old Son and I Endured in Family Detention, N.Y. Times (June 25, 2018), https:// www.nytimes.com/2018/06/25/opinion/family-detention-immigration.html [https://perma.cc/BKV9URWT].

88. Angelica Quintero, America's Love-Hate Relationship with Immigrants, L.A. TIMES (Aug. 2, 2017), https://www.latimes.com/projects/la-na-immigration-trends/ [https://perma.cc/3KSJ-DRU4]. 
